\title{
The PRINTO provisional definition of remission in juvenile dermatomyositis
}

\author{
D Lazarevic, A Pistorio, P Miettunen, A Ravelli, C Malattia, C Pilkington, N Wulffraat, S Garay, M Hofer, P Quartier, \\ P Dolezalova, I Calvo Penades, V Ferriani, G Ganser, O Kasapcopur, JA Melo-Gomes, M Wierzbowska, A Martini, \\ N Ruperto, for PRINTO
}

From 18th Pediatric Rheumatology European Society (PReS) Congress

Bruges, Belgium. 14-18 September 2011

\section{Objective}

To define a definition of remission in juvenile dermatomyositis (JDM) that is stringent but achievable and could be applied uniformly as an outcome measure in clinical trials.

\section{Methods}

275 patients in active phase of JDM $<18$ years, median disease duration 7.7 months, were evaluated at baseline and 24 months. Out of 275 patients, all patients (39/ 275) who were off treatment at 24 months were defined as being in clinical remission and were included as the "gold standard" group. A random sample of patients $(n=78)$ who were in an active phase of JDM at baseline and on medications at 24 months, were selected as the "comparison group". Literature was reviewed for definitions of remission and in addition other definitions were tested which included PRINTO core set variables, muscle enzymes, and other JDM activity measures. Accuracy measurements were calculated: sensitivity, specificity, Youden index, Cohen's kappa ( $\geq 0.8$ almost perfect).

\section{Results}

Four best single variables with kappa $\geq 0.8$ were Manual Muscle Testing (MMT) $\geq 78$ (sensitivity: 0.92, specificity 0.97, kappa 0.9), followed by Physician Global Assessment of Muscle Activity (PhyMAVAS) and Physician Global Visual Analogue Scale (PhyGloVAS) $\leq 0.2$ and Childhood Myositis Assessment Scale (CMAS) $\geq 48$. The most accurate combination of variables with kappa $\geq 0.8$ included 4 variables with 3 out of 4 required to be present: creatine phosphokinase $\leq 150, \quad C M A S \geq 48$,

* Correspondence: printo@ospedale-gaslini.ge.it

IRCCS G. Gaslini, Pediatria II, PRINTO, Italy

Full list of author information is available at the end of the article
MMT $\geq 78$, PhyGloVAS $\leq 0.2$ (sensitivity 0.94 , specificity 1.00, kappa 0.96).

\section{Conclusion}

The combination definition performed the best overall in defining remission in JDM and could be used for the evaluation of global response to therapy in future clinical trials.

Published: 14 September 2011

doi:10.1186/1546-0096-9-S1-P194

Cite this article as: Lazarevic et al:: The PRINTO provisional definition of remission in juvenile dermatomyositis. Pediatric Rheumatology 20119 (Suppl 1):P194.
Submit your next manuscript to BioMed Central and take full advantage of:

- Convenient online submission

- Thorough peer review

- No space constraints or color figure charges

- Immediate publication on acceptance

- Inclusion in PubMed, CAS, Scopus and Google Scholar

- Research which is freely available for redistribution
() Biomed Central
C Biomed Central

(c) 2011 Lazarevic et al; licensee BioMed Central Ltd. This is an open access article distributed under the terms of the Creative Commons Attribution License (http://creativecommons.org/licenses/by/2.0), which permits unrestricted use, distribution, and reproduction in any medium, provided the original work is properly cited. 